\title{
Measuring preventive procedures by French GPs: an observational survey
}

\author{
Marie Blanquet, Laurent Gerbaud, Chantal Noirfalise, \\ Pierre Michel Llorca, Claude Campagne and Jacques Malaval
}

\begin{abstract}
Background GPs, since a law was passed in March 2002.

Aim performed by French GPs.

Design of study

Observational survey.

Setting

GP surgeries in Puy-de-Dôme, France.

Method
\end{abstract}

Prevention has become a legal obligation for French

Measurement and analysis of preventive procedures

Doctors completed a questionnaire about their socioprofessional characteristics, and a researcher completed another questionnaire about preventive procedures performed on the last 15 patients seen by each GP. Twenty preventive services were evaluated and, for each service, medical records, targets, and objectives were defined according to the national preventive care guidelines. The gap between guidelines and practice was explained by doctor characteristics. Statistical analyses were performed using $\chi^{2}$ and logistic regression.

\section{Results}

Representative samples of 179 doctors and 2453 medical records were randomised. Four preventive services were performed in more than $75 \%$ of cases, and the gap was explained by the salaried job the doctors had. Ten preventive services were performed in $25 \%$ to $75 \%$ of cases and the gap was explained by the medical software used. The six remaining services were performed in less than $25 \%$ of cases and no explanatory variable was identified.

\section{Conclusion}

Sixteen preventive procedures were insufficiently performed. The more a preventive service is performed the more the gap will be explained by GPs' socioprofessional characteristics. The gap for a preventive procedure performed in $25 \%$ to $75 \%$ of cases was mainly explained by management of the medical records. A nationwide policy to improve prevention performance in general practice seems to be essential.

Keywords

general practitioner; preventive health services; primary health care.

\section{INTRODUCTION}

Apart from their own intrinsic efficacy, ${ }^{1-15}$ preventive services are more effective when carried out by primary healthcare doctors. ${ }^{16-19} \mathrm{~A}$ number of financial incentives have been developed worldwide to improve GPs' prevention performance, such as pay for performance in the UK, ${ }^{20}$ and the US..$^{21,22}$ In France, since the March 2002 law that added prevention to the Public Health Code and the August 2004 law that introduced GPs as 'gate keepers', prevention has become one of GPs' main tasks.

The current survey was based on the framework of two previous studies conducted in the university hospital of Clermont-Ferrand in 2004 and 2006. Fourteen preventive procedures and associated improvements were measured after various incentives were applied. These studies showed that the hospital partially failed to fulfil its prevention mission. ${ }^{23}$

The current study aimed to measure prevention performed by GPs according to the national preventive care guidelines and to assess the distance between guidelines and practice.

M Blanquet, GP, assistant of public health; C Noirfalise, statistician, Centre Hospitalier Universitaire de ClermontFerrand, Clermont-Ferrand, France. L Gerbaud, $M D, P h D$, chief of service, Public Health; PM Llorca, MD, PhD, chief of service, Psychiatry, Centre Hospitalier Universitaire de Clermont-Ferrand and Université d'Auvergne, Clermont-Ferrand, France. C Campagne, GP, Souvigny, France. J Malaval, GP, Pleaux, France.

Address for correspondence

Dr Marie Blanquet, Serice de Santé Publique,

Hôtel Dieu (CHU), Boulevard Léon Malfreyt, 63058 Clermont-Ferrand Cedex 1, France.

E-mail: mblanquet@chu-clermontferrand.fr

Submitted: 2 April 2010; Editor's response: 13 May 2010; final acceptance: 19 July 2010.

(C)British Journal of General Practice

This is the full-length article (published online 27 Dec 2010) of an abridged version published in print. Cite this article as: Br J Gen Pract 2011; DOI: 10.3399/bjgp11X548947. 


\section{METHOD}

This was an observational survey conducted in the French department of Puy-de-Dôme from July to September 2007 and is based on two questionnaires: one to identify GPs' socioprofessional characteristics the GP questionnaire and one to measure the preventive services they performed: the medical records questionnaire.

Inclusion criteria for medical records were: patient aged 18 years or over, examination by GP either at home or in the surgery, and follow-up by the same GP for at least 5 years. Exclusion criteria were: patient living in a nursing home, irrelevance of primary and secondary preventive services (palliative care), and a medical history of cardiovascular diseases (myocardial infarction, stroke, or peripheral arterial disease), cancer (breast, colon, cervix, or prostate), or dementia. Tertiary prevention was not studied because related preventive services and frequency are different.

\section{Medical record assessment}

The survey was based on auto-assessment by GPs of their medical records; they were interviewed by the researcher filling in the questionnaire. To be registered by the researcher, a preventive procedure had to be performed and noted in the medical records. No personal data were collected. One researcher filled in all the medical records questionnaire.

The preventive care guidelines of the French National Authority for Health (Haute Autorité de Santé) were followed to determine medical records targets and objectives of the 20 preventives services evaluated:6,24-36 diphtheria-tetanus-poliomyelitis, pertussis, and influenza immunisations; rubella serology and toxoplasmosis serology; tobacco consumption detailed in three categories (still smoking in the group previously known as smoker, detailed evaluation of both tobacco consumption and addiction using test); blood pressure check; screening for dyslipidaemia and diabetes; measures of weight, height, and body mass index (BMI); screening for breast, cervical, colorectal, and prostate cancers; alcohol consumption and addiction evaluation; and research for a cognitive disorder and a risk of falling.

\section{GP and medical records questionnaires}

The GP questionnaire (Appendix 1) evaluated doctors' socioprofessional characteristics that are likely to have an impact on prevention procedures and investigated: sex of GPs; date of graduation; type of practice; location of facilities; salaried job; medical records; continuing medical education; student training; any other activity linked to medicine; and how the doctors used their spare time. These characteristics were the explanatory variables. This

\section{How this fits in}

The medical records questionnaire, based on medical records data, is available

to measure both the prevention performed at the hospital and at the GPs'

surgery. The main results and determinants found in this study suggest that a national preventive policy strengthening GPs in the primary healthcare doctor

role is essential to improve the health of the French population.

questionnaire was tested on the first $10 \mathrm{GPs}$.

The medical records questionnaire (Appendix 2) was developed from questionnaires used for the prevention studies carried out in the authors' university hospital, and was adapted to general practice. The questionnaire was tested during the interviews that the researcher had with the first three included GPs.

\section{Characteristics of concordance levels}

Preventive activity performance was classified into three groups: 'high', 'middle', and 'low', with preventive procedures performed in more than $75 \%$ of cases, in $25 \%$ to $75 \%$ of cases, or less than $25 \%$ of cases respectively. A search was carried out to see if there was concordance between these three performance groups and the determinants that had previously been identified.

\section{Randomisation methods used to select GPs and medical records}

The regional union of GPs selected all professionally active GPs in 2007 with a surgery in the study area for at least 5 years (some GPs may belong to a regional union without medical activity or work for the drug industry). They assigned each one a code and randomised them. Then, they produced a main list of 200 GPs and a secondary list of 150 GPs according to the CNIL rules (National Committee for Ethics in Informatics). All GPs of the main list were contacted by the researcher. If a GP refused, another was contacted from the secondary list.

Patients were randomised by the researcher at each GP's surgery. All patients were checked to see if they met inclusion/exclusion criteria, and if so they were included in the study, starting with the last patient who was examined on their last working day. Inclusion stopped when 10 to 15 patients were included.

\section{Number of participants needed}

Using the highest prevalence among diseases targeted by the preventive services evaluated, 2305 participants were needed for a $2 \%$ precision measure and an $\alpha$ error of $5 \%$. To take account of GPs' workload, the number of questionnaires that needed to be completed per GP was 10 to 15, and the number of GPs needed was 153 to 230 . 


\section{Statistical analyses}

Two descriptive analyses were performed: one relating to GPs' socioprofessional characteristics, and one relating to the prevention performances. As the variables were qualitative, $\chi^{2}$ tests and logistic regression were successively performed to compare physicians' attitudes toward prevention and to identify meaningful explanatory variables based on the calculation of the adjusted odds ratio. A meaningful threshold of $10 \%$ was chosen for the bivariate analysis in order not to neglect any interesting variables.

A meaningful threshold of $5 \%$ was chosen for the multivariate analysis and the likelihood ratio test. A logistic regression model was valid when the percentage of concordance was at least $60 \%$. Statistical analysis was performed using SAS software. Finally, to give a broader view of factors related to the prevention performance, an aggregated score was calculated on Excel software for each explanatory variable, by combining the step of entry into the model and the number of variables in each model.

\section{RESULTS}

Among the population of 565 GPs selected and randomised, 350 GPs were included in the two lists and 261 GPs were contacted; 179 agreed to participate, 72 refused, and 10 were excluded (seven had undergone surgery within the last 5 years, and three were not practising as GPs in 2007). The sampling rate was $68.6 \%$. The sample was representative of the population (Table 1). Characteristics of GPs, as explanatory variables, are shown in Table 2.

Randomisation of the medical records was in accordance with the study protocol, except for two GPs who preferred to receive the questionnaires by post and one who selected medical records by alphabetical order. The response rates ranged from $99.2 \%$ to $100 \%$ according to preventive services; 2453 medical records were included.

GPs' prevention performance is presented in Table 3. The 'high' group ( $\geq 75 \%$ preventive procedures) contained four procedures: blood pressure check,

\begin{tabular}{|c|c|c|c|}
\hline & $\begin{array}{c}\text { GP population, } \\
n(\%)\end{array}$ & $\begin{array}{c}\text { Sample, } \\
n(\%)\end{array}$ & $P$-value \\
\hline \multicolumn{4}{|l|}{ Sex } \\
\hline Male & $390(71.04)$ & $121(67.60)$ & 0.1551 \\
\hline Female & 159 (28.96) & $58(32.40)$ & 0.1551 \\
\hline \multicolumn{4}{|c|}{ Type of location for facilities ${ }^{a}$} \\
\hline City & $221(40.26)$ & $66(36.87)$ & 0.1780 \\
\hline Outskirts & $142(25.87)$ & $50(27.93)$ & 0.2638 \\
\hline Isolated city & $65(11.84)$ & $21(11.73)$ & 0.4822 \\
\hline Rural & $121(22.04)$ & $42(23.46)$ & 0.3229 \\
\hline
\end{tabular}

according to the definition of the National Institute for Statistics and Economic Studies. ${ }^{37}$ screening for dyslipidaemia and diabetes, and measurement of weight. The 'middle' group (25-75\%) included 10 procedures: pertussis, diphtheria-tetanuspoliomyelitis, and influenza immunisations; rubella serology; still smoking or not, and detailed evaluation of tobacco consumption in the smoking group; measurement of height and $\mathrm{BMl}$; and screening for breast, colorectal, and prostate cancers. The 'low' group (<25\%) included six services: toxoplasmosis serology; cervical cancer screening; alcohol consumption and addiction evaluation; and research for a cognitive disorder and a risk of falling.

The main results of the bivariate analysis revealed that GPs who graduated recently performed less prevention than those who graduated at least 15 years ago. Female doctors performed more preventive activities, except for BMl assessment. GPs with a salaried activity performed fewer preventive procedures, especially those working in institutions for older people. Despite better results when GPs had computerised medical records, none of the medical software available allowed sufficient collection of all the preventive services evaluated.

Logistic regression analysis showed 12 meaningful models out of 20 possible (Appendix 3). Overall, when a preventive service was classified 'high', two main explanatory variables were identified by the logistic regression: 'salaried job' the GPs had, and 'having a cultural leisure activity'. GPs who worked in institutions for older people performed less prevention than those who had a salaried activity at a hospital. When a procedure was in the 'middle' group, the main explanatory variable identified by the logistic regression for five models on the seven models performed, was the 'software' the GPs used. Moreover, the detailed results showed that all modalities of this explanatory variable were meaningful. When a service belonged to the 'low' group, no determinant was found, so the results will be treated in specific articles.

Finally, the aggregated score was calculated. For example, for the 'pertussis immunisation' model, the first variable entered was 'software', so that scored one point (3/3); the second was 'sex' (scored 0.66 points, $2 / 3$ ); and the last was 'practising any kind of sport' (scored 0.33 points, $1 / 3$ ). This score was calculated for all explanatory variables and was summed per variable (Appendix 4). The variable 'software', which entered into $66.7 \%$ of the models, had the highest aggregated score (7.12). The variables 'salaried job' and 'having a cultural leisure activity', entered into $50.0 \%$ of the models, had a score that was higher than 4 (respectively 4.41 and 4.08). Finally, the variables 'sex', 'practising any kind of sport', and 'reading without a link to medicine', entered into $50.0 \%, 66.7 \%$, and $41.7 \%$ of the models respectively, obtained scores between 3 and 4 (3.78, 3.63, and 3.46 respectively). 
The remaining variables, entered in less than $60.0 \%$ of the models, had a score that was less than 3 .

\section{DISCUSSION}

\section{Summary of main findings}

Cardiovascular risk factors were thoroughly evaluated by GPs, apart from the annual evaluation of tobacco consumption, which needs to be enhanced. Results obtained for height and BMI measures were insufficient because of the increased prevalence of overweight (29.5\%) and obesity (10.7\%), ${ }^{38}$ and a prevalence of undernourishment of around $7-10 \%$ in general practice. $^{39}$ All immunisations were insufficiently performed and also need to be improved. Nonetheless, three explanations are possible concerning pertussis immunisation: the guideline was relatively new (2004), the targeted patients were not defined precisely enough, and this vaccine is only available in association with the diphteria-tetanus-poliomyelitis vaccination which is performed every 10 years.

Preventive services targeting fertile women showed a lack of communication between GPs and medical gynaecologists. The worst result was obtained for the evaluation of alcohol consumption: $11.22 \%$ of patients were asked about their alcohol consumption, whereas the prevalence of alcohol misuse seen in a general practice is $30 \%{ }^{40}$ Bivariate analysis identified sex, date of graduation, salaried job, and medical record as the main determinants of difference between practice and guidelines.

A concordance was found between the level of performance and identified determinants. The more a preventive service is performed, the more the departure from guidelines will be explained by the GPs' socioprofessional characteristics, whereas the departure for a preventive procedure belonging to the 'middle' group was mainly explained by management of the medical records. The aggregated scores strengthened the evidence that all available software was irrelevant, despite a better performance of prevention when medical records were computerised.

\section{Strengths and limitations of the study}

The entire study protocol was followed as expected; both the sampling rates and the response rate were high; the sample was representative of the given population; and the number of participants included was sufficient. The survey has three limitations. First, GPs were free to choose whether to participate, so those who accepted probably performed better preventive procedures. Second, translation of the preventive care guidelines into the study questionnaire objectives was more difficult for brief interventions in the case of addiction than translation of the recommended frequency for the other services. Consequently, the study only measured if consumption
Table 2. Characteristics of GPs as explanatory variables.

\begin{tabular}{|c|c|c|}
\hline Explanatory variables & & $n(\%)$ \\
\hline Sex & Male & $121(67.60)$ \\
\hline & Female & $58(32.40)$ \\
\hline Location of facilities $^{a}$ & City & $66(36.87)$ \\
\hline & Outskirts & $50(27.93)$ \\
\hline & Isolated city & $21(11.73)$ \\
\hline & Rural & $42(23.46)$ \\
\hline Date of graduation & Recent (5-15 years) & $36(20.11)$ \\
\hline & Moderately recent (15-30 years) & $109(60.89)$ \\
\hline & Older ( $\geq 30$ years) & 34 (18.99) \\
\hline Practice & Solo & $92(51.40)$ \\
\hline & In a group & $87(48.60)$ \\
\hline Salaried job & None & $132(73.74)$ \\
\hline & Hospital & $12(6.70)$ \\
\hline & Institution for older people & $12(6.70)$ \\
\hline & Other & $23(12.85)$ \\
\hline Medical record & Computerised & $67(37.43)$ \\
\hline & On paper & $38(21.23)$ \\
\hline & Both & $74(41.34)$ \\
\hline Software & None & $38(21.30)$ \\
\hline & Doc'Ware & $7(3.91)$ \\
\hline & HelloDoc & $14(7.82)$ \\
\hline & Médiclick! & $24(13.41)$ \\
\hline & Axisanté 5 & $23(12.85)$ \\
\hline & Eglantine & $31(17.32)$ \\
\hline & MédiStory & $11(6.15)$ \\
\hline & Crossway-ville & $6(3.35)$ \\
\hline & Software created by the GP themselves & $7(3.91)$ \\
\hline & Other & $18(10.60)$ \\
\hline Continuing medical & Reading medical journals & $158(88.27)$ \\
\hline education (CME) & Medical journals with reading test & $46(25.70)$ \\
\hline & Peer-review participation & $44(24.58)$ \\
\hline & Local CME meetings & $135(75.42)$ \\
\hline & Regional and national seminars & $101(56.42)$ \\
\hline & Other & $48(26.82)$ \\
\hline Medical students training & Yes & $32(17.88)$ \\
\hline & No & $147(82.12)$ \\
\hline Participation in another & Yes & $63(35.20)$ \\
\hline activity linked to medicine & No & $116(64.80)$ \\
\hline Reading with no link & More than once per week & $133(74.30)$ \\
\hline to medicine & Once per week & $26(14.53)$ \\
\hline & Once per month/less than once per month/never & $20(11.17)$ \\
\hline Having a cultural & More than once per week/once per week & $16(8.94)$ \\
\hline leisure activity & Once per month & 68 (37.99) \\
\hline & Less than once per month/never & $95(53.07)$ \\
\hline Practising any kind & More than once per week & 59 (32.96) \\
\hline of sport & Once per week & $56(31.28)$ \\
\hline & Once per month/less than once per month/never & $64(35.75)$ \\
\hline
\end{tabular}

${ }^{a}$ According to the definition of the National Institute for Statistics and Economic Studies.

of alcohol or tobacco appeared in the medical record. Third, a procedure was only registered if it was noted in the medical records, so the results are probably underestimated, especially for immunisations because some GPs only note them on a vaccination card.

\section{Comparison with existing literature}

Two previous French studies confirm the poor results for diphteria-tetanus-poliomyelitis immunisation. ${ }^{41,42}$ 


\begin{tabular}{|c|c|c|c|c|}
\hline \multicolumn{5}{|c|}{ Performance } \\
\hline Categories & Preventive procedures & $(\%)$ & $95 \% \mathrm{Cl}(\%)$ & $n$ \\
\hline \multirow{5}{*}{$\begin{array}{l}\text { Vaccinations } \\
\text { and serologies }\end{array}$} & Diphtheria-tetanus-poliomyelitis & 44.84 & 42.87 to 46.81 & 2453 \\
\hline & Pertussis & 28.95 & 24.60 to 33.30 & 418 \\
\hline & Rubella & 34.97 & 30.45 to 39.48 & 429 \\
\hline & Toxoplasmosis & 14.38 & 8.69 to 20.08 & 146 \\
\hline & Influenza & 52.66 & 49.33 to 55.98 & 866 \\
\hline \multirow{7}{*}{$\begin{array}{l}\text { Cardiovascular } \\
\text { risk factor }\end{array}$} & Smoking assessment in the population: & 11.40 & 10.14 to 12.66 & 2448 \\
\hline & $\begin{array}{l}\text { Still smoking in the group previously } \\
\text { known as smoker }\end{array}$ & 56.74 & 51.80 to 61.68 & 386 \\
\hline & $\begin{array}{l}\text { Detailed evaluation of tobacco } \\
\text { consumption }\end{array}$ & 48.70 & 43.72 to 53.69 & 386 \\
\hline & Evaluation of tobacco addiction using test & 5.44 & 3.18 to 7.70 & 386 \\
\hline & Blood pressure & 95.68 & 94.87 to 96.48 & 2452 \\
\hline & Dyslipidaemia screening & 92.84 & 91.64 to 94.04 & 1774 \\
\hline & Screening for diabetes & 93.53 & 92.43 to 94.64 & 1887 \\
\hline \multirow[t]{3}{*}{ Anthropometry } & Measurement of weight & 78.23 & 76.60 to 79.86 & 2453 \\
\hline & Measurement of height & 45.33 & 43.36 to 47.30 & 2453 \\
\hline & Measurement of body mass index & 25.64 & 23.91 to 27.37 & 2453 \\
\hline \multirow[t]{4}{*}{ Cancers } & Breast cancer & 62.48 & 59.05 to 65.91 & 765 \\
\hline & Cervical cancer & 23.54 & 21.15 to 25.94 & 1202 \\
\hline & Colorectal cancer & 51.61 & 48.64 to 54.59 & 1085 \\
\hline & Prostate cancer & 63.70 & 55.90 to 71.50 & 146 \\
\hline \multirow[t]{2}{*}{ Addictions } & Evaluation of alcohol consumption & 11.22 & 9.97 to 12.47 & 2451 \\
\hline & Evaluation of alcohol addiction using test & 0.57 & 0.27 to 0.87 & 2451 \\
\hline \multirow{2}{*}{$\begin{array}{l}\text { Cognitive } \\
\text { disorders }\end{array}$} & $1 \mathrm{MMSE}^{\mathrm{a}}$ performed & 13.35 & 10.07 to 16.63 & 412 \\
\hline & MMSE performed in the last year & 7.04 & 4.57 to 9.51 & 412 \\
\hline \multirow[t]{5}{*}{ Risk of falling } & Asking 'have you ever fallen?' & 2.19 & 0.77 to 3.60 & 411 \\
\hline & 'Up and go' test & 1.95 & 0.61 to 3.28 & 411 \\
\hline & Walking and talking & 1.70 & 0.45 to 2.95 & 411 \\
\hline & Standing on one foot & 1.70 & 0.45 to 2.95 & 411 \\
\hline & Sternal press & 1.22 & 0.16 to 2.28 & 411 \\
\hline
\end{tabular}

${ }^{a}$ Mini-Mental State Examination. screening agency, ${ }^{47}$ the percentage of this study was found to be higher $(P<0.001)$. This difference can be explained by the fact that women who had a mammography outside the regional screening programme are included in the present study but not in the agency one. For colorectal cancer, the study results were also higher than those of the regional screening agency $(P<0.001)$. As for both breast and colorectal cancers, the 2007 report of the regional screening agency noticed a difference of performance between cities and rural areas. The bivariate analysis used in this study did not produce the same finding. The present study showed better results than a previous one based on 2-3 years of screening $(P=0.047){ }^{48}$

\section{Implications for clinical practice and further research}

French GPs have a heavy workload, time constraints, and fee-for-service remuneration that does not include incentives for prevention. A better organisation of primary health care based on the standardisation of medical software for preventive procedures and the coordination of medical professionals may reduce GPs' workload; more preventive services could be delivered by nurses, especially in the new 'Health House', an establishment grouping together different health workers like GPs, nurses, physiotherapists, which is mainly developed in rural areas. A different method of payment, such as pay for performance or per capita with preventive goals, could be introduced to induce more appropriate incentives. In the UK, pay for performance for GPs seems to have produced significant improvements for preventive services and chronic diseases. ${ }^{49,50}$

GPs systematically perform four preventive procedures. In this case, a second salaried job in institutions for older people and a monthly cultural leisure activity are linked to the distance between practice and guidelines. Other preventive services are insufficiently performed, especially immunisations, measurement of height, screenings targeting fertile women, and evaluation of alcohol consumption. When a service was performed in $25 \%$ to $75 \%$ of cases, the medical software GPs used was the main determinant identified. No software allows a global and systematic collection of prevention data. These three explanatory variables also had the highest aggregated score.

Consequently, to achieve better prevention performance, a national public health programme should be developed, simultaneously taking into account initial training and appropriate continuing medical education for all doctors, improving the tools for managing medical records with the addition of another kind of payment, evaluating preventive performance, and training nurses to perform some preventive services. 


\section{Funding body}

Faculty of Medicine, University of Auvergne.

\section{Ethics committee}

The project was presented and accepted by the ethics committee of the general practice department of the Faculty of Medicine at Clermont-Ferrand.

\section{Competing interests}

The authors have stated that there are none.

\section{Acknowledgements}

With thanks to the 179 GPs who participated to this study.

\section{Discuss this article}

Contribute and read comments about this article on the Discussion Forum: http://www.rcgp.org.uk/bjgp-discuss

\section{REFERENCES}

1. Antona D. Le tétanos en France en 2005-2007. Bulletin Épidémiologique Hebdomadaire de l'Institut National de Veille Sanitaire 2008; 30-31: 273-275.

2. Antona D. Surveillance des entérovirus en France 2001-2003: maladies a prévention vaccinale, Surveillance nationales des maladies infectieuses 2001-2003. Saint-Maurice: Institut National de Veille Sanitaire, 2005.

3. Gross PA, Hermogenes AW, Sacks HS, et al. The efficacy of influenza vaccine in elderly persons, a meta-analysis and review of the literature. Ann Intern Med 1995; 123(7): 518-527.

4. Nichol KL, Wuorenma J, Von Sternberg T. Benefits of influenza vaccination for low-, intermediate-, and high-risk senior citizens. Arch Intern Med 1998; 158(16): 1769-1776

5. Armstrong BG, Mangtani P, Fletcher A, et al. Effect of influenza vaccination on excess deaths occurring during periods of high circulation of influenza: cohort study in elderly people. BMJ 2004; 329(7467): 660.

6. Haute Autorité de Santé. Méthodes d'évaluation du risque cardiovasculaire global. Saint-Denis La Plaine: Service Evaluation en Santé Publique, 2004.

7. Mandel JS, Church TR, Bond JH, et al. The effect of faecal occult-bloo screening on the incidence of colorectal cancer. N Engl J Med 2000; 343(22): 1603-1607.

8. Hardcastle JD, Chamberlain JO, Robinson MH, et al. Randomised controlled trial of faecal-occult-blood screening for colorectal cancer. Lancet 1996; 348(9040): 1472-1477.

9. Kronborg O, Fenger C, Olsen J, et al. Randomised study of screening for colorectal cancer with faecal-occult-blood test. Lancet 1996: 348(9040): $1467-1471$

10. Faivre J, Tazi MA, El Mrini T, et al. Faecal occult blood screening and reduction of colorectal cancer mortality: a case-control study. Br J Cancer 1999; 79(3-4): 680-683.

11. Humphrey LL, Helfand M, Chan BK, Woolf SH. Breast cancer screening: a summary of the evidence for the U.S. Preventive Services Task Force. Ann Intern Med 2002; $137(5$ part 1):347-360.

12. International Agency for Research on Cancer (IARC). Cervix cancer screening. In: IARC handbook of cancer prevention. Lyon: IARC, 2005; 10.

13. Agence Française de Sécurité Sanitaire des Produits de Santé (Afssaps). Les stratégies thérapeutiques médicamenteuses et non médicamenteuses de l'aide à l'arrêt du tabac, recommandations. Saint Denis: Afssaps, 2003.

14. International Agency for Research on Cancer. Tobacco control: reversal of risk after quitting smoking. In: IARC Handbooks of Cancer Prevention. Lyon: IARC, 2007: 11.

15. Anderson P. Effectiveness of general practice interventions for patients with harmful alcohol consumption. Br J Gen Pract 1993; 43(374): 386-389.

16. Ferrante JM, Gonzalez EC, Pal N, Roetzheim RG. Effects of physician supply on early detection of breast cancer. J Am Board Fam Pract 2000; 13(6): $408-414$

17. Roetzheim RG, Gonzalez EC, Ramirez A, et al. Primary care physician supply and colorectal cancer. J Fam Pract 2001; 50(12): 1027-1031.

18. Campbell RJ, Ramirez AM, Perez K, Roetzheim RG. Cervical cancer rates and the supply of primary care physicians in Florida. Fam Med 2003; 35(1): 60-64

19. Flocke SA, Stange KC, Zyzanski SJ. The association of attributes of primary care with the delivery of clinical preventive services. Med Care 1998; 36(Suppl 8): AS21-30.

20. Roland M. Linking physicians' pay to the quality of care. A major experiment in the United Kingdom. N Engl J Med 2004; 351(14): 1448-1454.

21. Epstein AM, Lee TH, Hamel MB. Paying physicians for high-quality care. N Engl J Med 2004; 350(4): 406-410

22. Baker G, Delbanco S. Pay for performance: national perspective. 2006 longitudinal survey results with 2007 market updates. http://www.ehcca.com/presentations/pfpsummit3/linscott_1.pdf (accessed 29 Nov 2010)

23. Blanquet M, Grondin MA, Noirfalise C, Gerbaud L. How a university hospital improves its prevention performance: results of two biennial studies 2004-2006. J Prev Med Hyg 2010; 51(1): 44-49.
24. Conseil supérieur d'hygiène publique de France. Calendrier vaccinal 2006. Bulletin epidemiologique hebdomadaire de l'Institut de Veille Sanitaire 2006; 29-30: 211-226.

25. Agence Française de Sécurité Sanitaire des Aliments. Toxoplasmose: état des connaissances et évaluation du risque lié à l'alimentation, Rapport du groupe de travail 'toxoplasma gondii' de l'Afssa. Maisons-Alfort: Afssa, 2005.

26. Haute Autorité de Santé. Stratégies thérapeutiques d'aide au sevrage tabagique. Saint-Denis La Plaine: HAS, service évaluation économique et santé publique, 2007; 37-38.

27. Haute Autorité de Santé. Prise en charge des patients atteints d'hypertension artérielle. Saint-Denis La Plaine: HAS, service des recommandations professionnelles, 2005.

28. Agence Francaise de Sécurité Sanitaire des Produits de Santé. Prise en charge thérapeutique du patient dyslipidémique. Saint-Denis: Agence Française de Sécurité Sanitaire des Produits de Santé, 2005.

29. Haute Autorité de Santé. Traitement médicamenteux du diabète non insulinodépendant. Saint-Denis La Plaine: HAS, service des recommandations professionnelles, 2006; 12-13.

30. Haute Autorité de Santé. Le dépistage du cancer du sein par mammographie dans la population générale. Saint-Denis La Plaine: HAS, service des recommandations professionnelles, 1999.

31. Haute Autorité de Santé. Conduite à tenir devant un frottis anormal du col de l'utérus. Saint-Denis La Plaine: HAS, service des recommandations professionnelles, 1998.

32. Advisory Committee on Cancer Prevention. Recommendations on screening in the European Union. Eur J Cancer 2000; 36(12): 1473-1478.

33. Haute Autorité de Santé. Opportunité d'un dépistage systématique du cancer de la prostate par le dosage de l'antigène spécifique de la prostate. Saint-Denis La Plaine: HAS, service des recommandations professionnelles, 1998.

34. Société Française d'Alcoologie. Les conduites d'alcoolisation. Recommandations pour la pratique clinique. Alcoologie et Addictologie 2001; 23(Suppl 4): 67S-75S.

35. Haute Autorité de Santé. Recommandations pratiques pour le diagnostic de la maladie d'Alzheimer. Saint-Denis La Plaine: HAS, service des recommandations professionnelles, 2000.

36. Société Française de Documentation et de Recherche en Médecine Générale (SFDRMG). Prévention des chutes accidentelles chez la personne âgée. Montreuil: SFDRMG.

37. Institut national de la statistique et des etudes économiques (INSEE) Définitions.

http://www.insee.fr/fr/methodes/default.asp?page=definitions/listedefinitions.htm (accessed 29 Nov 2010).

38. Lanoë JL, Dumontier F. Tabagisme, abus d'alcool et excès de poids. Paris INSEE Première, 2005 .

39. Expertise collective de l'Institut Nationale de la Santé et de la Recherche Médicale (INSERM). Carences nutritionnelles, étiologies et dépistage. Paris INSERM, 1999.

40. Direction de la Recherche des Etudes, de l'Evaluation et des Statistiques (DREES). Le risque d'alcoolisation excessive : des écarts entre les déclarations des patients et l'avis des médecins. DREES Etudes et Résultats 2005; 405.

41. Guthmann JP, Fonteneau L, Antona D, Lévy-Bruhl D. La couverture vaccinale diphtérie, tétanos, poliomyélite chez l'adulte en France: résultats de l'enquête Santé et protection Sociale. Bulletin Épidémiologique Hebdomadaire de l'Institut de Veille Sanitaire 2007; 51-52: 441-445.

42. Gergely A, Bechet S, Goujon C, et al. La couverture vaccinale contre le tétanos, la poliomyélite et la diphtérie en 2006 dans une population âgée francilienne. Bulletin Épidémiologique Hebdomadaire de l'Institut de Veille Sanitaire 2008; 9: 64-69.

43. Pham HH, Schrag D, Hargraves JL, Bach PB. Delivery of preventive services to older adults by primary care physicians. JAMA 2005; 294(4): 473-481.

44. Schwarz Chávarri $\mathrm{H}$, Pedrera Carbonell V, Ortuño López JL, et al. Influence of physician and physician list characteristics on influenza vaccination rates in older people in a health care area in the community of Valencia, Spain. Aten Primaria 2004; 34(7): 336-342.

45. Birgé J. Audit sur la surveillance du poids en médicine générale. Rev Prat Med Gen 1999; 448: 222-225.

46. Mission Interministerielle pour la Lutte contre le Cancer. Cancer: le plan de mobilisation nationale. Paris: Mission Interministerielle pour la Lutte contre le Cancer, 2002.

47. Association Régionale des Dépistages Organisés des Cancers (ARDOC) Rapport d'activité. Clermont Ferrand: ARDOC, 2007.

48. Aubert JP, Falcoff $H$, Florès $P$, et al. Dépistage mammographique individual du cancer du sein chez les femmes de 50 à 69 ans : audit de pratique de 41 médecins généralistes d'Ile-de-France. Rev Prat Med Gen 1995; 300: 40-51.

49. Campbell S, Reeves D, Kontopantelis E, et al. Quality of primary care in England with the introduction of pay for performance. N Engl J Med 2007; 357(2): 181-190.

50. Millett C, Gray J, Saxena S, et al. Impact of a pay for performance incentive on support for smoking cessation and on smoking prevalence among people with diabetes. CMAJ 2007; 176(12): 1705-1710 


\section{Appendix 1. The GP questionnaire.}

\section{GP characteristics}

1. GP number

2. How many years ago did you graduate?
$\square$ 5-15
$\square$ 15-30
$\square$ more than 30

Characteristics of your medical activity

3. Do you practise:
$\square$ solo?
$\square$ in a group?

4. Do you also have a salaried job?

$\square$ yes

$\square$ no

5. If 'yes' what sort of job is it?
$\square$ in an hospital
$\square$ in an infant and mother health centre
$\square$ other

6. If 'other', please specify

7. Your medical files are recorded (2 answers are possible):
$\square$ on a computer
$\square$ on paper

8. If your medical records are computerised, would you tell us which software you are using

9. Do you participate in continuing medical education (CME)?
$\square$ yes
$\square$ no

10. If 'yes' what kind of CME do you perform? (several answers are possible)
$\square$ reading medical journals
$\square$ medical journals with reading test
$\square$ peer review
$\square$ meetings organised by local formal CME groups
$\square$ seminars organised by regional or national formal CME groups
$\square$ other

11. If 'other', please specify

12. Do you accept medical students for their first or second training period in your surgery?
$\square$ yes
$\square$ no

13. Do you participate to another kind of activity linked to medicine?
$\square$ yes
$\square$ no

14. If 'yes', please specify:

$\square$ trade unionism

$\square$ teaching at the medical university of Clermont-Ferrand

$\square$ politics

$\square$ medical counci

$\square$ organisation of formal CME

$\square$ member of an organisation or an association

$\square$ other

15. If 'other', please specify 


\section{Appendix 1 continued. The GP questionnaire.}

\section{Characteristics of your spare time}

16. Do you read any books, papers, journals with no link to medicine?
$\square$ yes
$\square$ no

17. If 'yes', would you specify how many times per week or per month:
$\square$ more than once a week
$\square$ once a week
$\square$ at least once a month
$\square$ less than once a month

18. Do you go to the cinema, theatre, concert, opera...?
$\square$ yes
$\square$ no

19. If 'yes', please specify how many time per week or per month:
$\square$ more than once a week
$\square$ once a week
$\square$ at least once a month
$\square$ less than once a month

20. Do you practise any kind of sporting activity?
$\square$ yes
$\square$ no

21. If 'yes', please specify how many time per week or per month:
$\square$ more than once a week
$\square$ once a week
$\square$ at least once a month
$\square$ less than once a month 


\section{Appendix 2. The medical records questionnaire.}

\begin{tabular}{|c|c|c|c|c|c|}
\hline \multicolumn{6}{|c|}{ Number of GPs interviewed } \\
\hline \multicolumn{2}{|c|}{ Please circle the correct answer: Y (yes); N (no); NA (not applicable) } & \multicolumn{4}{|l|}{ Number of medical records questionnaire } \\
\hline Preventive services & Targets & Aims & $\mathrm{Me}$ & sures & \\
\hline \multicolumn{6}{|l|}{ Vaccinations and serology tests } \\
\hline Diphtheria & All patients & Last immunisation $<10$ years & $\mathrm{Y}$ & $\mathrm{N}$ & \\
\hline Tetanus & All patients & Last immunisation $<10$ years & Y & $\mathrm{N}$ & \\
\hline Pertussis & Patients aged $\leq 40$ years & Last immunisation $<10$ years & Y & $\mathrm{N}$ & NA \\
\hline Poliomyelitis & All patients & Last immunisation $<10$ years & $\mathrm{Y}$ & $\mathrm{N}$ & \\
\hline Rubella & Fertile women & 1 vaccination checked or serology performed & Y & $\mathrm{N}$ & NA \\
\hline Toxoplasmosis & Fertile nulliparous women & 1 serology test performed & Y & $\mathrm{N}$ & NA \\
\hline Influenza & Patients aged $\geq 65$ years & Last immunisation $<1$ year & Y & $\mathrm{N}$ & NA \\
\hline \multicolumn{6}{|l|}{ Cardiovascular risk factors } \\
\hline Age & All patients & Men aged $>50$ years or women aged $>60$ years & $\mathrm{Y}$ & $\mathrm{N}$ & \\
\hline Tobacco & All patients & Last evaluation of whether a smoker or not $<1$ year & $\mathrm{Y}$ & $\mathrm{N}$ & \\
\hline Blood pressure & All patients & Last measurement $<1$ year & Y & $\mathrm{N}$ & \\
\hline Dyslipidaemia screening test & $\begin{array}{l}\text { Patients aged }<80 \text { years and with } \\
\text { one cardiovascular risk factor, or } \\
\text { patients aged } \geq 80 \text { years old if a } \\
\text { treatment was started before the } \\
\text { age of } 80 \text { years }\end{array}$ & Last dyslipidaemia screening test $<3$ years & Y & $\mathrm{N}$ & NA \\
\hline Screening for diabetes & $\begin{array}{l}\text { Patient with at least one } \\
\text { cardiovascular risk factor }\end{array}$ & Last sugar blood sample $<3$ years & Y & $\mathrm{N}$ & NA \\
\hline \multicolumn{6}{|l|}{ Anthropometry } \\
\hline Measurement of weight & All patients & Last measure $<1$ year & $\mathrm{Y}$ & $\mathrm{N}$ & \\
\hline Measurement of height & All patients & Last measure $<1$ year & $\mathrm{Y}$ & $\mathrm{N}$ & \\
\hline Measurement of body mass index & All patients & Last measure $<1$ year & Y & $\mathrm{N}$ & \\
\hline \multicolumn{6}{|l|}{ Cancers } \\
\hline Breast cancer & $\begin{array}{l}\text { Women aged over } 50 \text { and up } \\
\text { to } 74 \text { years }\end{array}$ & Last mammography $<2$ years & Y & $\mathrm{N}$ & NA \\
\hline Cervix cancer & $\begin{array}{l}\text { Women aged over } 20 \text { and up to } \\
74 \text { years with no medical history } \\
\text { of cervical surgery }\end{array}$ & Last smear test $<2$ years & Y & $\mathrm{N}$ & NA \\
\hline Colorectal cancer & $\begin{array}{l}\text { Patients aged over } 50 \text { and up to } \\
74 \text { years if the date of the last } \\
\text { colonoscopy for another reason } \\
\text { than colorectal cancer was }>5 \text { years }\end{array}$ & $\begin{array}{l}\text { Last faecal occult blood screening } \\
<2 \text { years }\end{array}$ & Y & $\mathrm{N}$ & NA \\
\hline Prostate cancer & Patients $\geq 75$ years & Last question and clinical exam $<1$ year & Y & $\mathrm{N}$ & NA \\
\hline \multicolumn{6}{|l|}{ Addiction } \\
\hline \multirow{2}{*}{ Alcohol consumption } & All patients & Last measure of consumption $<1$ year & Y & $\mathrm{N}$ & \\
\hline & & $\begin{array}{l}\text { Last classification of sort of addiction used, for } \\
\text { example CAGE assessment for alcohol abuse }<1 \text { year }\end{array}$ & Y & $\mathrm{N}$ & \\
\hline \multirow[t]{2}{*}{ Tobacco consumption } & Smokers & $\begin{array}{l}\text { Last measure of consumption in number of packets } \\
\text { a year or in number of cigarette per day }<1 \text { year }\end{array}$ & $\mathrm{Y}$ & $\mathrm{N}$ & \\
\hline & & $\begin{array}{l}\text { Last classification of sort of addiction used, for } \\
\text { example the Fagerström test for nicotine dependence } \\
\text { for physical }<1 \text { year }\end{array}$ & $\mathrm{Y}$ & $\mathrm{N}$ & \\
\hline \multicolumn{6}{|l|}{ Cognitive disorders } \\
\hline \multirow[t]{2}{*}{ Mini-Mental State Examination (MMSE) } & Patients $\geq 75$ years & At least one MMSE performed & $\mathrm{Y}$ & $\mathrm{N}$ & NA \\
\hline & Patients $\geq 75$ years & Last MMSE $<1$ year & $\mathrm{Y}$ & $\mathrm{N}$ & NA \\
\hline \multicolumn{6}{|l|}{ Risk of falling } \\
\hline Asking 'have you ever fallen?' & Patients $\geq 75$ years & Last evaluation $<1$ year & $\mathrm{Y}$ & $\mathrm{N}$ & NA \\
\hline 'Up and go' test & Patients $\geq 75$ years & Last evaluation $<1$ year & $\mathrm{Y}$ & $\mathrm{N}$ & NA \\
\hline Walking and talking & Patients $\geq 75$ years & Last evaluation $<1$ year & $\mathrm{Y}$ & $\mathrm{N}$ & NA \\
\hline Standing on one foot & Patients $\geq 75$ years & Last evaluation $<1$ year & Y & $\mathrm{N}$ & NA \\
\hline Sternal press & Patients $\geq 75$ years & Last evaluation $<1$ year & Y & $\mathrm{N}$ & NA \\
\hline
\end{tabular}




\section{Appendix 3. Main results of the logistic regression, result of the likelihood ratio test $(\mathrm{P})$, and adjusted odds ratio (OR).}

\begin{tabular}{|c|c|c|c|c|c|c|c|c|c|}
\hline & & & $<$ performa & percentage & $5 \%$ & & & Performance per & rcentage $>75 \%$ \\
\hline & $\begin{array}{l}\text { BMI } \\
(P<0.001)\end{array}$ & $\begin{array}{l}\text { Pertussis } \\
\text { immunisation } \\
(P<0.001)\end{array}$ & $\begin{array}{l}\text { DTP } \\
\text { immunisation } \\
(P<0.001)\end{array}$ & $\begin{array}{l}\text { Height } \\
(P<0.001)\end{array}$ & $\begin{array}{l}\text { Influenza } \\
\text { immunisation } \\
(P<0.001)\end{array}$ & $\begin{array}{l}\text { Tobacco } \\
\text { 'smoking } \\
\text { group' }\end{array}$ & $\begin{array}{l}\text { Breast } \\
\text { cancer } \\
(P<0.001)\end{array}$ & $\begin{array}{l}\text { Weight } \\
\text { measurement } \\
(P<0.001)\end{array}$ & $\begin{array}{l}\text { BP } \\
\text { measurement } \\
(P=0.001)\end{array}$ \\
\hline 1. & $\begin{array}{l}\text { Software } \\
\text { (OR 73.78) }\end{array}$ & $\begin{array}{l}\text { Software } \\
\text { (OR 16.71) }\end{array}$ & $\begin{array}{l}\text { Software } \\
\text { (OR 3.04) }\end{array}$ & $\begin{array}{l}\text { Software } \\
\text { (OR 8.04) }\end{array}$ & $\begin{array}{l}\text { Software } \\
\text { (OR 10.40) }\end{array}$ & $\begin{array}{l}\text { Sex } \\
\text { (OR 2.02) }\end{array}$ & $\begin{array}{l}\text { Peer review } \\
\text { (OR 1.72) }\end{array}$ & $\begin{array}{l}\text { Salaried job } \\
\text { (OR 4.49) }\end{array}$ & $\begin{array}{l}\text { Salaried } \\
\text { job (OR 4.09) }\end{array}$ \\
\hline 2. & $\begin{array}{l}\text { Read } \\
\text { (OR 2.94) }\end{array}$ & $\begin{array}{l}\text { Sex } \\
\text { (OR 1.83) }\end{array}$ & $\begin{array}{l}\text { Medical } \\
\text { record } \\
\text { (OR 2.60) }\end{array}$ & $\begin{array}{l}\text { Location of } \\
\text { facilities } \\
\text { (OR 3.05) }\end{array}$ & $\begin{array}{l}\text { Sport } \\
\text { (OR 2.26) }\end{array}$ & $\begin{array}{l}\text { Medical } \\
\text { practice } \\
\text { (OR 1.83) }\end{array}$ & $\begin{array}{l}\text { Read } \\
\text { (OR 3.57) }\end{array}$ & $\begin{array}{l}\text { Cultural } \\
\text { activity } \\
\text { (OR 1.72) }\end{array}$ & $\begin{array}{l}\text { Cultural } \\
\text { activity } \\
\text { (OR 2.24) }\end{array}$ \\
\hline 3. & $\begin{array}{l}\text { Salaried job } \\
\text { (OR 9.51) }\end{array}$ & $\begin{array}{l}\text { Sport } \\
\text { (OR 1.65) }\end{array}$ & $\begin{array}{l}\text { Sex } \\
\text { (OR 1.53) }\end{array}$ & $\begin{array}{l}\text { Salaried job } \\
\text { (OR 2.70) }\end{array}$ & $\begin{array}{l}\text { Read } \\
\text { (OR 2.13) }\end{array}$ & $\begin{array}{l}\text { Cultural } \\
\text { activity } \\
\text { (OR 3.69) }\end{array}$ & $\begin{array}{l}\text { Software } \\
\text { (OR 0.46) }\end{array}$ & $\begin{array}{l}\text { Medical } \\
\text { record } \\
\text { (OR 2.09) }\end{array}$ & $\begin{array}{l}\text { Software } \\
\text { (OR 18.70) }\end{array}$ \\
\hline 4. & $\begin{array}{l}\text { Medical } \\
\text { students } \\
\text { training } \\
\text { (OR 1.71) }\end{array}$ & & $\begin{array}{l}\text { Sport } \\
\text { (OR 1.44) }\end{array}$ & $\begin{array}{l}\text { Read } \\
\text { (OR 1.81) }\end{array}$ & $\begin{array}{l}\text { Regional/ } \\
\text { national CME } \\
\text { seminars } \\
\text { (OR 1.46) }\end{array}$ & $\begin{array}{l}\text { Another } \\
\text { activity linked } \\
\text { to medicine } \\
\text { (OR 1.67) } \\
\end{array}$ & $\begin{array}{l}\text { Cultural } \\
\text { activity } \\
\text { (OR 2.48) }\end{array}$ & $\begin{array}{l}\text { Local CME } \\
\text { meetings } \\
\text { (OR 1.78) }\end{array}$ & $\begin{array}{l}\text { Date of } \\
\text { graduation } \\
\text { (OR 5.02) }\end{array}$ \\
\hline 5. & $\begin{array}{l}\text { Location of } \\
\text { facilities } \\
\text { (OR 3.18) }\end{array}$ & & $\begin{array}{l}\text { Location of } \\
\text { facilities } \\
\text { (OR 1.37) }\end{array}$ & $\begin{array}{l}\text { Date of } \\
\text { graduation } \\
\text { (OR 1.92) }\end{array}$ & $\begin{array}{l}\text { Medical } \\
\text { students } \\
\text { training } \\
\text { (OR 1.57) }\end{array}$ & & $\begin{array}{l}\text { Date of } \\
\text { graduation } \\
\text { (OR 1.61) }\end{array}$ & $\begin{array}{l}\text { Read } \\
\text { (OR 2.40) }\end{array}$ & $\begin{array}{l}\text { Sex } \\
\text { (OR 3.11) }\end{array}$ \\
\hline 6. & $\begin{array}{l}\text { Local CME } \\
\text { meetings } \\
\text { (OR 1.81) }\end{array}$ & & $\begin{array}{l}\text { Another } \\
\text { activity linked } \\
\text { to medicine } \\
\text { (OR 1.26) }\end{array}$ & $\begin{array}{l}\text { Another } \\
\text { activity linked } \\
\text { to medicine } \\
\text { (OR 1.56) }\end{array}$ & & & & $\begin{array}{l}\text { Sport } \\
\text { (OR 1.55) }\end{array}$ & $\begin{array}{l}\text { Sport } \\
\text { (OR 2.17) }\end{array}$ \\
\hline 7. & $\begin{array}{l}\text { Reading test } \\
\text { (OR 1.48) }\end{array}$ & & $\begin{array}{l}\text { Reading test } \\
\text { (OR 1.25) }\end{array}$ & $\begin{array}{l}\text { Sport } \\
\text { (OR 1.50) }\end{array}$ & & & & $\begin{array}{l}\text { Reading of } \\
\text { medical journals } \\
\text { (OR 1.49) }\end{array}$ & \\
\hline 8. & $\begin{array}{l}\text { Cultural activity } \\
\text { (OR 1.75) }\end{array}$ & & & $\begin{array}{l}\text { Regional/ } \\
\text { national CME } \\
\text { seminars } \\
\text { (OR 1.35) } \\
\end{array}$ & & & & $\begin{array}{l}\text { Peer review } \\
\text { (OR 1.37) }\end{array}$ & \\
\hline 9. & $\begin{array}{l}\text { Medical record } \\
\text { (OR 21.52) }\end{array}$ & & & & & & & & \\
\hline 10. & $\begin{array}{l}\text { Regional/national } \\
\text { CME seminars } \\
\text { (OR 1.54) }\end{array}$ & & & & & & & & \\
\hline 11. & $\begin{array}{l}\text { Date of graduatior } \\
\text { (OR 2.45) }\end{array}$ & & & & & & & & \\
\hline 12. & $\begin{array}{l}\text { Another activity } \\
\text { linked to medicine } \\
\text { (OR 1.69) }\end{array}$ & & & & & & & & \\
\hline 13. & Sport (OR 1.37) & & & & & & & & \\
\hline 14. & Sex (OR 1.29) & & & & & & & & \\
\hline
\end{tabular}




\section{Appendix 4. Results of the aggregated scores for all the explanatory variables tested, classified from the higher score to the lower score.}

\begin{tabular}{lcc} 
Explanatory variable & $\begin{array}{c}\text { Percentage of model in which the } \\
\text { explanatory variable is meaningful }\end{array}$ & \begin{tabular}{l} 
Aggregated score \\
\hline Software
\end{tabular} \\
\hline Salaried job & 56.7 & 7.12 \\
\hline Having a cultural leisure activity & 50 & 4.41 \\
\hline Sex & 50 & 4.08 \\
\hline Practising any kind of sport & 66.7 & 3.78 \\
\hline Reading with no link to medicine & 41.7 & 3.63 \\
\hline Location of facilities & 33.3 & 3.46 \\
\hline Date of graduation & 58.3 & 2.70 \\
\hline Peer review participation & 25 & 2.56 \\
\hline Medical records & 25 & 2.13 \\
\hline Another activity linked to medicine & 33.3 & 2.01 \\
\hline Regional or national CME seminars & 33.3 & 1.58 \\
\hline Local CME meetings & 16.7 & 1.43 \\
\hline Practice & 16.7 & 1.23 \\
\hline Medical students training & 16.7 & 1.08 \\
\hline Medical journals with reading test & 16.7 & 1 \\
\hline Reading medical journals & 8.3 & 0.68 \\
\hline Other type of CME & 8.3 & 0.25 \\
\hline
\end{tabular}

$C M E$ = continuing medical education 